\title{
Glandular odontogenic cyst: case series and summary of the literature
}

\author{
SADJ October 2019, Vol. 74 No. 9 p502 - p507
}

F Opondo', S Shaik², J Opperman ${ }^{3}$, CJ Nortjé ${ }^{4}$

\begin{abstract}
The glandular odontogenic cyst (GOC) remains a rare entity. It was initially named "sialo-odontogenic cyst" by Padayachee and Van Wyk in 1987 when they reported the first two cases. Thereafter the term glandular odontogenic cyst was suggested by Gardner et al. in 1988 and was subsequently adopted by the $\mathrm{WHO}{ }^{1}$
\end{abstract}

In addition to its rarity, it has non-pathognomonic clinical and radiological features and hence can mimic other lesions. Since its recognition as an entity by the WHO in 1992, only two further cases of glandular odontogenic cyst have been seen at the authors' institution and are hereby reported together with a summary of the review articles in the English literature.

\section{Keywords}

Developmental jaw cyst, glandular cyst, recurrent cyst.

\section{INTRODUCTION}

The glandular odontogenic cyst is a rare developmental cyst. ${ }^{2}$ Its clinical and radiological presentation are generally non-specific. It closely mimics other odontogenic lesions that exhibit slow, invasive growth, little cortical expansion and high recurrence rates and thus the definitive diagnosis can only be confirmed by histopathology.

\section{Author affiliations:}

1. Florence Opondo: BDS (UON), MSc. MFR (PG), Department of Diagnostics and Radiology, Faculty of Dentistry, University of the Western Cape, South Africa.

ORCID Number: 0000-0002-9794-677X

2. Shoayeb Shaik: $B C h D, P D D, M S c$. (UWC) (MFR), HOD, Department of Diagnostics and Radiology, Faculty of Dentistry, University of the Western Cape, South Africa.

ORCID Number: 0000-0002-4898-3005

3. Johan Opperman: $B S c, B C h D, P D D, M C h D$, Consultant Oral and Maxillofacial Pathologist. National Health Laboratory Services (NHLS), Cape Town, South Africa.

ORCID Number: 0000-0002-9684-6670

4. Christoffel J Nortjé: BChD, PhD, Dip. ABOMR, DSc., Senior Professor, Department of Diagnostics and Radiology, Faculty of Dentistry, University of the Western Cape, South Africa. ORCID Number: 0000-0002-9717-5514

Corresponding author: Florence Opondo

Department of Diagnostics and Radiology, Faculty of Dentistry, University of the Western Cape, Cape Town, South Africa.

Email: floekea@yahoo.com

Author contributions:

1. Florence Opondo: Identification of cases, compiling clinical information, literature review, writing manuscript - $40 \%$

2. Shoayeb Shaik: Radiological images and interpretation - $20 \%$

3. Johan Opperman: Histological sections and diagnosis $-20 \%$

4. Christoffel J Nortjé: Overall appraisal and final editing of manuscript - $20 \%$
Histologically, it may mimic any one of a dentigerous cyst, radicular cyst, surgical ciliated cyst, lateral periodontal cyst or a botryoid odontogenic cyst. Importantly, the features of a cystic lesion with squamous and mucous epithelial elements may cause it to be misdiagnosed as a central mucoepidermoid carcinoma.

With more comprehensive diagnostic criteria, at least 180 cases have so far been reported in the English literature. ${ }^{4}$ It is therefore reasonable to assume that the previous rarity of this entity may be attributable to misdiagnosis.

\section{CASE 1}

A 60-year-old man presented at the diagnostic clinic at Tygerberg Oral Health Centre with an asymptomatic swelling of the anterior mandible. The lesion caused buccal expansion and "egg shell" thinning of the bony buccal cortex.

Panoramic radiography revealed a radiolucent lesion in the anterior mandible, extending from 35 to 46. It was moderately well defined, partially corticated with a scalloped outline.

The internal structure was non-homogenous with multiple septae. There was no displacement of teeth nor root resorption. CBCT imaging confirmed a multilocular cystic lesion with perforation of buccal and lingual cortices (Figure 1).

A differential radiologic interpretation of multicystic ameloblastoma, odontogenic keratocyst and central giant cell granuloma was made.

Aspiration biopsy confirmed the presence of cystic fluid. Surgical enucleation was performed. Histopathological examination revealed a multilocular cyst lined by a non-keratinizing, cuboidal to columnar epithelium of variable thickness.

The epithelial lining demonstrated epithelial spherules, surface eosinophilic cuboidal cells (hobnail cells) exhibiting focal apocrine changes and cells with clear to vacuolated cytoplasm at the basal/parabasal layer.

Ciliated surface cells were also noted as were papillary projections of the epithelium into the cyst lumen. Mucicarmine stain was positive for mucin in goblet cells and in intra-epithelial microcystic (glandular or pseudoglandular) spaces. The morphological features were compatible with a glandular odontogenic cyst (Figure 2). 


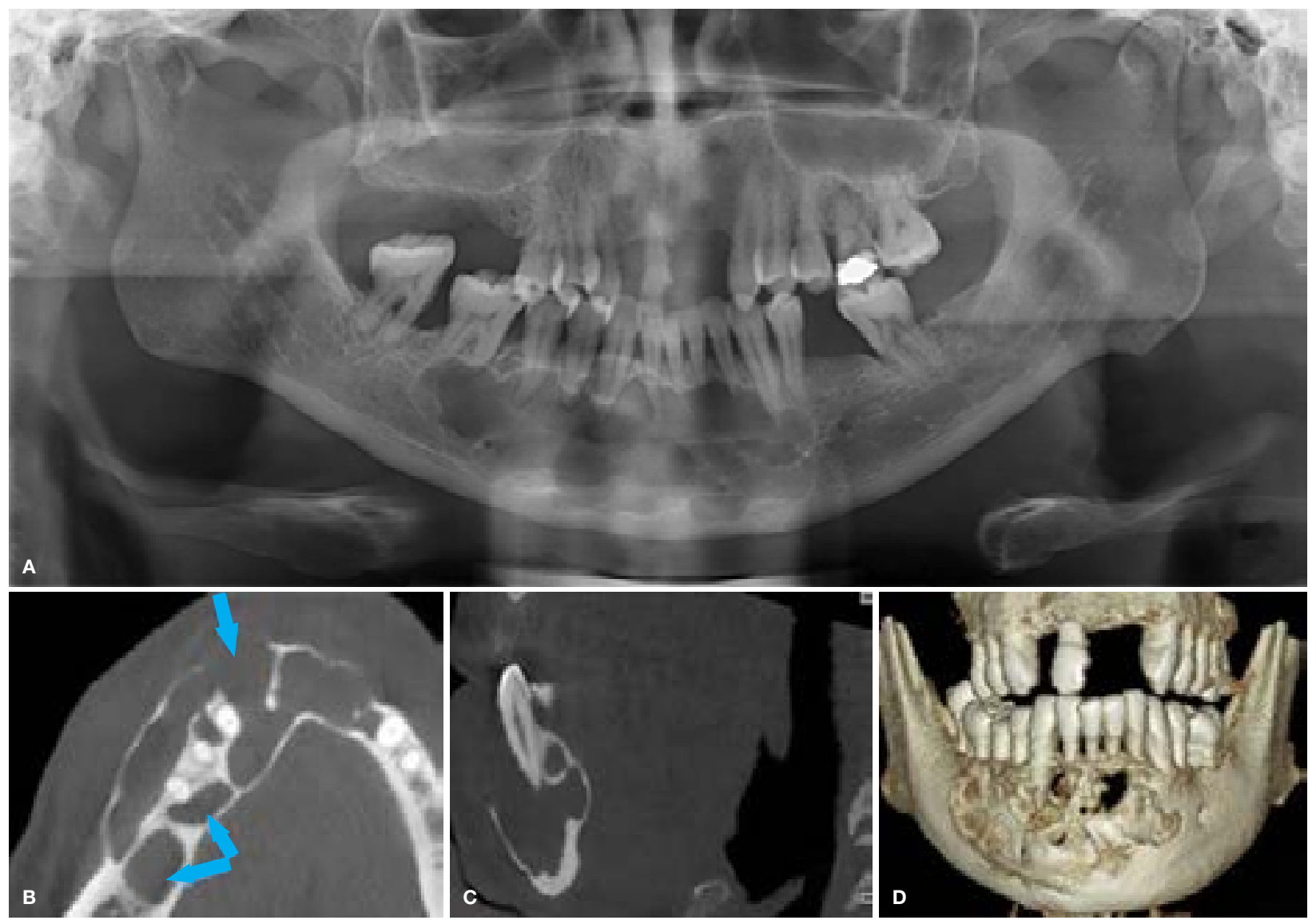

Figure 1. A: Panoramic radiograph at initial presentation;

B: CBCT axial section demonstrating multilocularity and cortical perforation;

C: CBCT Sagittal section demonstrating mild antero-posterior expansion and cortical perforation;

D: CBCT 3D reconstruction.
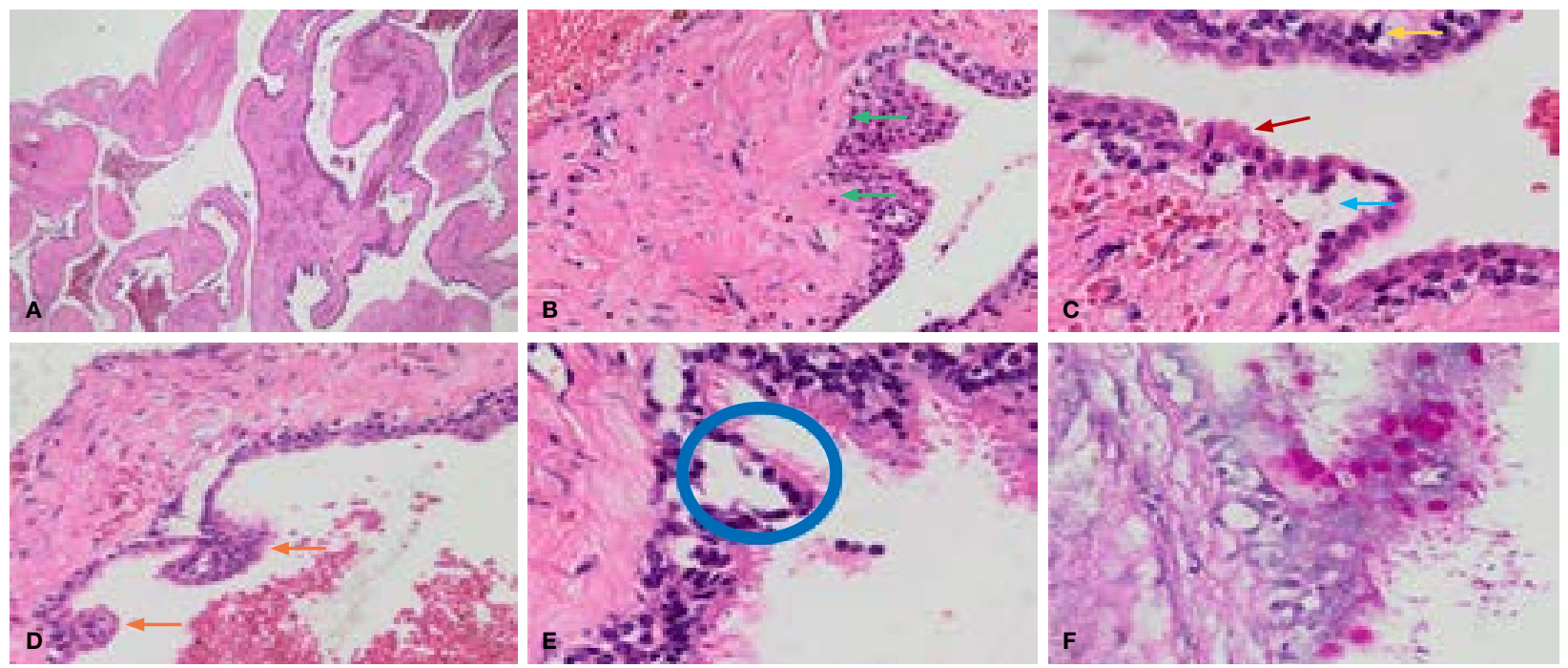

Figure 2. A: Multiple cystic spaces, lined by non-keratinizing, cuboidal to columnar epithelium (H\&E X2);
B: Cyst lining demonstrating epithelial spherules (H\&EX4):
C: Hobnail cells on the luminal surface showing apocrine changes (red arrow), clear to vacuolated cells at the basal/parabasal layer
(yellow arrow) and microcystic spaces (blue arrow) (H\&E x4);

D: Papillary projections into cyst lumen (orange arrow) (H\&E x2);

E: Cilia (H\&E X20);

F: Mucous goblet cells in the cyst lining (Mucicarmine positive) H\&E X2O 


\section{CASE 2}

A 59-year-old female presented with an expansile lesion of the anterior mandible with a five month history. The swelling extended from 33-45 and had caused bucco-lingual expansion. It was generally asymptomatic but had become painful in the past three weeks.

The associated teeth were mobile. The patient was known to be HIV positive and was already taking antiretroviral medication. A differential diagnosis of ameloblastoma or odontogenic keratocyst was made. Panoramic radiography revealed multiple missing teeth, but more importantly the missing 31 and 41 related to the cystic lesion. There was a unilocular radiolucent lesion in the anterior mandible, extending from 34 to 46.

It was well defined and exhibited a smooth outline. Its lateral and inferior borders were well corticated, but the superior border was not discernible. The internal structure was homogenous and without septae. There was displacement of teeth and root resorption (Figure 3).

Surgical enucleation was performed. Microscopic sections revealed reactive trabecular bone with an attached cystic structure lined by non-keratinizing stratified squamous epithelium of variable thickness.
An intense chronic inflammatory infiltrate was seen in the connective tissue wall. Cilia were absent, however, microcysts, mucous cells, clear cells, papillary projections and eosinophilic hobnails cells were all present.

Corrugation of the superficial layer was noted. PAS and Mucicarmine stains were positive. The morphological features were compatible with an inflamed glandular odontogenic cyst (Figure 4). A panoramic radiograph performed one year after enucleation showed no signs of recurrence (Figure 5).

\section{DISCUSSION}

Little was known about the glandular odontogenic cyst until recently. It was initially named sialo-odontogenic cyst due to the presence of mucous cells, mucin pools and eosinophilic cuboidal cells that mimicked salivary gland ducts. ${ }^{5}$

In 1988, Gardner et al. described it as glandular odontogenic cyst after establishing that it contained mucin elements, was lined by odontogenic epithelium and lacked salivary tissue.

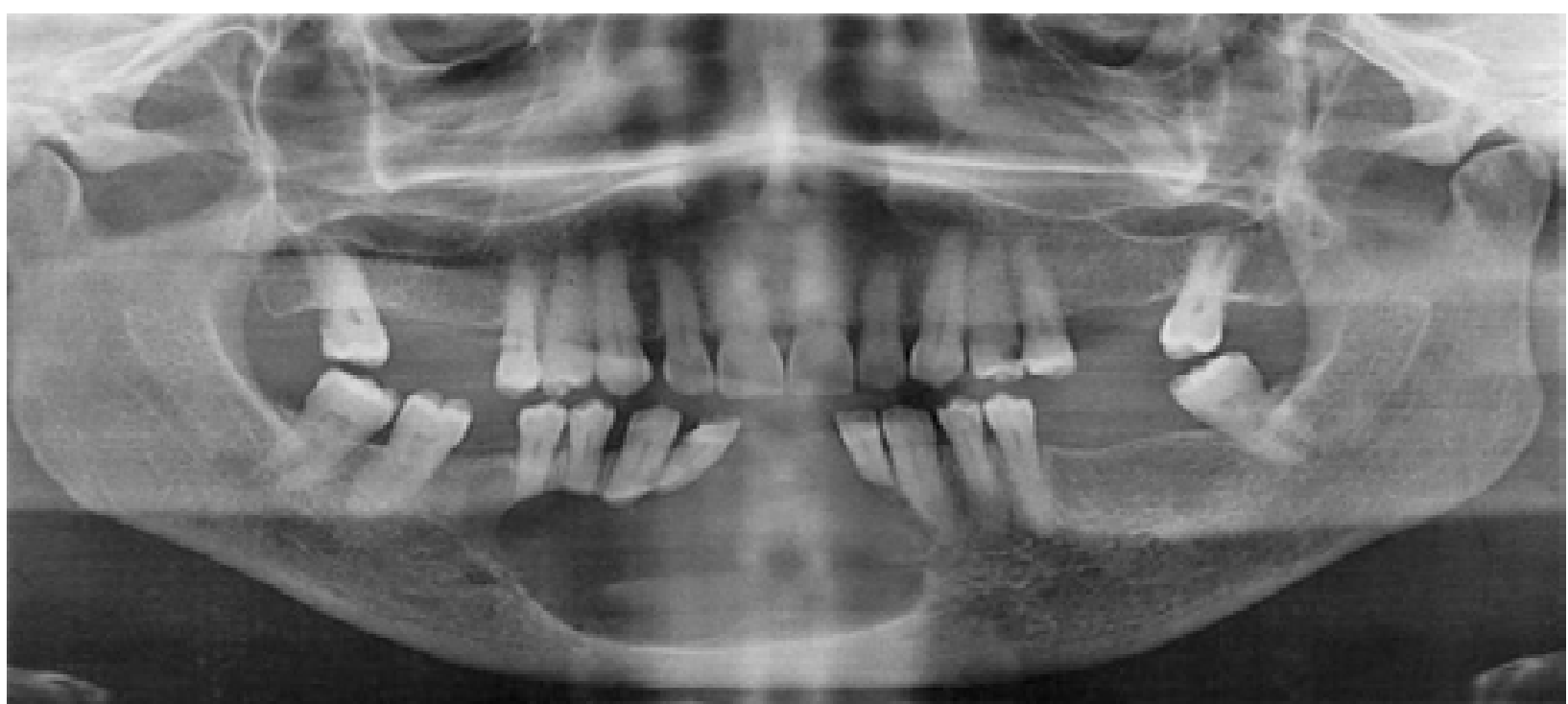

Figure 3. Panoramic radiograph at initial presentation.
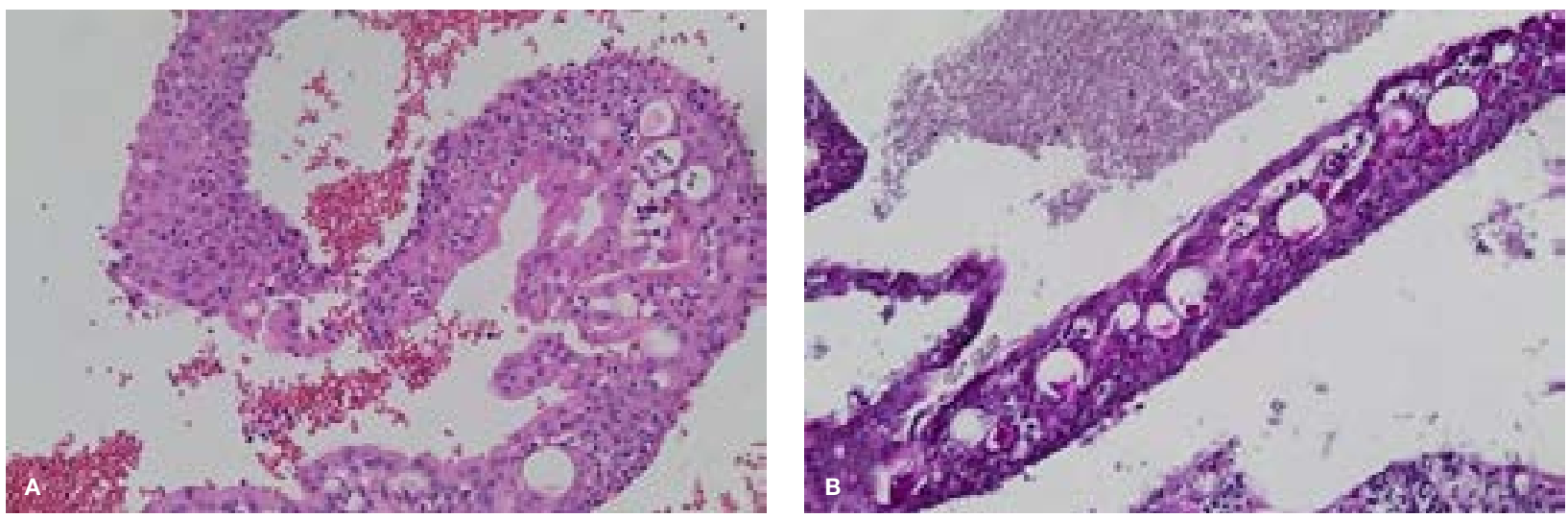

Figure 4. A: Cyst lining showing eosinophilic luminal hobnail cells, microcysts, mucous cells, papillary projections and clear cells (400 $\mathrm{x}$ magnification). B: PAS \& D positive for mucin in microcyst ( $400 \times$ magnification). 


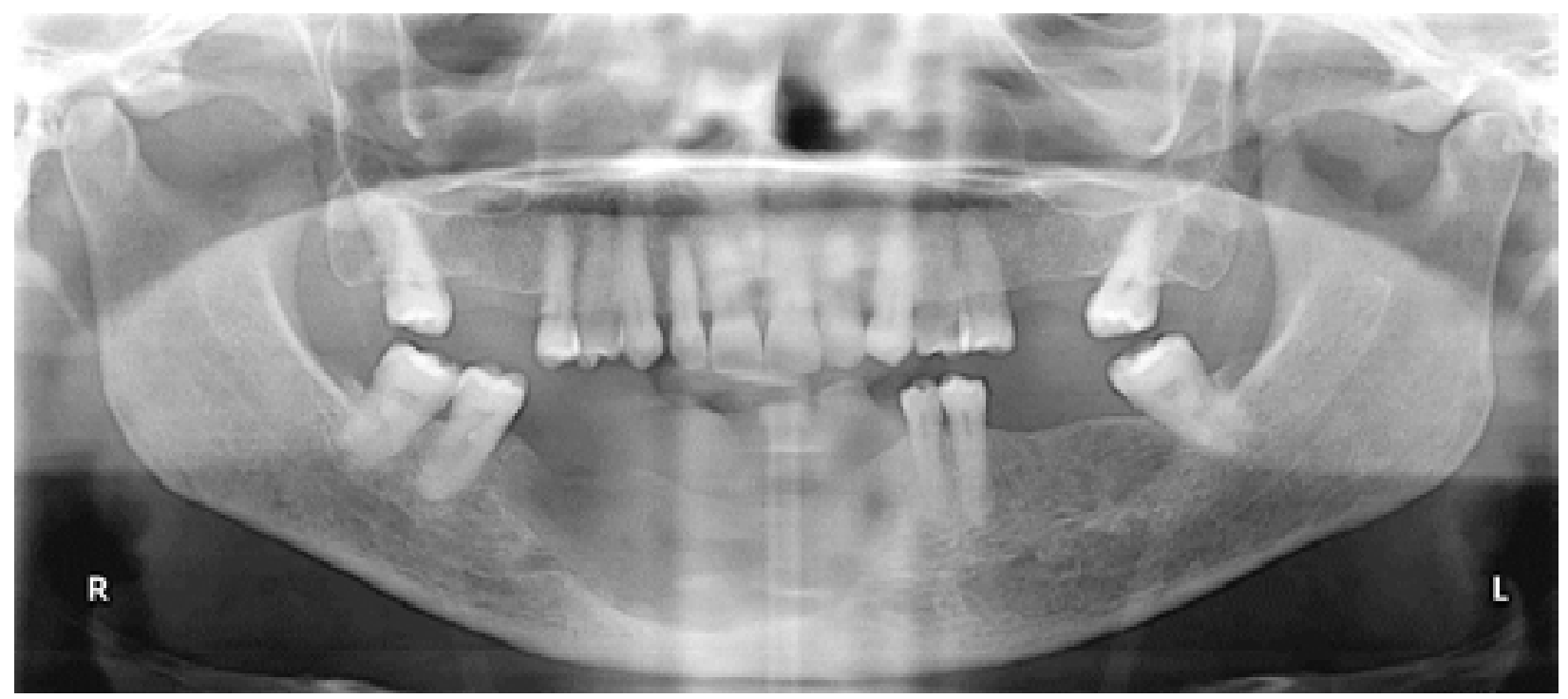

Figure 5. Panoramic radiograph 1-year post-operatively. No evidence of recurrence.

The term glandular odontogenic cyst was adopted by $\mathrm{WHO}$ in 1992. It is currently classified as a developmental cyst of odontogenic origin. ${ }^{6}$

The glandular odontogenic cyst still has the lowest incidence (0.12-0.13\%) of all odontogenic cysts. ${ }^{4}$ However, Ogura ${ }^{7}$ reported a slightly higher prevaence in a Japanese study, where 4 of 144 patients with odontogenic cysts $(2.8 \%)$ had GOC. Since the recognition of this cyst by the WHO in 1992, only the two cases in this report have been diagnosed at the Tygerberg Hospital's National Health Service Laboratory.

Both cases involved the anterior mandible of patients aged 60 and 59 years respectively. This finding concurs with most published studies wherein the majority of glandular odontogenic cysts (72-80\%) are reported to occur in the anterior mandible of middle aged adults, with a peak in the $6^{\text {th }}$ decade. ${ }^{8}$ Many studies suggest equal gender distribution with a slight male predominance. . $^{2,4,6,7}$

The present cases included one male and one female. Until recently, the microscopic diagnosis of GOC has been based on major and minor criteria. ${ }^{8,9}$ Currently, the diagnostic criteria outlined by WHO (2017) requires the presence of a minimum of seven of 10 specific criteria. $^{10}$

Criteria for diagnosis of GOC by WHO, 2017. ${ }^{10}$

Features that must be present in all cases:

- Variable thickness of the epithelium lining the cyst, from two to three cell layers of squamous or cuboidal cells to thick stratified squamous epithelium.

- A luminal layer of cuboidal to low columnar cells (hob-nail cells) present at least focally.

\section{Features present in most cases:}

- Intraepithelial microcysts.

- Apocrine metaplasia of the luminal cells.

- Clear cells in the basal and parabasal layers.

- Papillary projections (tufting) into the lumen.

- Mucous cells.

\section{Other additional microscopic features:}

- Epithelial spheres similar to those seen in lateral periodontal cysts.

- Presence of cilia.

- Multiple cystic compartments.

GOCs have been found to be constantly negative for MAML2 gene rearrangements present in central mucoepidermoid carcinoma, suggesting the two are different entities.

However, the small number of cases tested cannot preclude the possibility that central mucoepidermoid carcinoma or even an ameloblastoma can develop from a pre-existing GOC. ${ }^{10,11}$

The radiological presentation of the glandular odontogenic cyst is not pathognomonic. ${ }^{12}$ It demonstrates characteristics of a benign but potentially aggressive tumour. ${ }^{13}$ It may present as a unilocular or multilocular lesion with a scalloped border and well-defined sclerotic rim.

Cortical expansion and perforation are seen in most cases. A periapical relationship with the affected teeth is seen, but in rare cases it appears as a perifollicular radiolucency. ${ }^{14}$

In common with many studies, both cases presented as well defined radiolucencies of the anterior mandible with varying degrees of cortication. However, the two lesions differed with regard to the peripheral outline, internal structure, and the displacement and resorption of dentition.

In terms of management, it has been suggested that surgical enucleation should be accompanied by adjunctive procedures due to the high recurrence rate, while post treatment follow up should continue for a minimum of three years. ${ }^{15,16}$

At this point, most publications on GOC have been single case reports and short case series. There are few detailed review articles (Table 1). 
Table 1. A summary of review articles of reported GOC

\begin{tabular}{|c|c|c|c|c|c|c|c|c|}
\hline Author & $\begin{array}{l}\text { No. of } \\
\text { cases }\end{array}$ & $\begin{array}{l}\text { Gender } \\
\text { (M:F) }\end{array}$ & Age & Site & Radiology & Treatment & Recurrence & Follow-up \\
\hline (16) & 56 & $1.6: 1$ & $\begin{array}{c}14-74 \\
\text { Mean } 48\end{array}$ & $\begin{array}{l}73.2 \% \\
\text { Mand } \\
26.8 \% \\
\text { Max }\end{array}$ & $\begin{array}{c}\text { Unilocular } \\
53.6 \% \\
\text { Multilocular } \\
46.4 \% \\
\text { CE 53.6\% } \\
\text { CP 39.3\% }\end{array}$ & $\begin{array}{l}\text { Curretage/ } \\
\text { marsupialisation/ } \\
\text { enucleation } \\
80.4 \% \\
\text { Peripheral } \\
\text { ostectomy/ } \\
\text { resection } \\
14.6 \% \\
\text { Conservative 5\% }\end{array}$ & $29.2 \%$ & $\begin{array}{c}\text { Mean } \\
2.9 \\
\text { years }\end{array}$ \\
\hline (12) & 111 & $1.3: 1$ & $\begin{array}{c}14-75 \\
\text { Mean } \\
45.7\end{array}$ & $\begin{array}{l}70 \% \\
\text { Mand } \\
30 \% \\
\text { Max }\end{array}$ & $\begin{array}{l}\text { Unilocular } \\
53.8 \% \\
\text { Multilocular } \\
46.2 \% \\
\text { CE } 88.5 \% \\
\text { CP } 61 \%\end{array}$ & $\begin{array}{c}\text { Curettage/enucleation } \\
83.5 \% \\
\text { Resection } \\
17 \%\end{array}$ & $\begin{array}{c}35.9 \% \\
0 \%\end{array}$ & $\begin{array}{c}\text { Mean } \\
2.7 \\
\text { years }\end{array}$ \\
\hline (8) & 46 & $1: 1$ & $\begin{array}{c}\text { Mean } \\
51\end{array}$ & $\begin{array}{l}80 \% \\
\text { Mand } \\
20 \% \\
\text { Max }\end{array}$ & $\begin{array}{l}\begin{array}{c}\text { Unilocular } 27 \\
\text { cases }\end{array} \\
\text { Multilocular } 14 \\
\text { cases } \\
5 \text { cases-NR } \\
\text { CE } 43 \text { cases } \\
\text { CP } 3 \text { cases }\end{array}$ & Enucleation/curretage & $19.6 \%$ & $\begin{array}{c}\text { Mean } \\
8.75 \\
\text { years }\end{array}$ \\
\hline (15) & 169 & $1.2: 1$ & $\begin{array}{c}12-90 \\
\text { Mean } \\
48.1\end{array}$ & $\begin{array}{l}73.2 \% \\
\text { Mand } \\
26.8 \% \\
\text { Max }\end{array}$ & $\begin{array}{l}\text { Unilocular } \\
61.5 \% \\
\text { Multilocular } \\
38.5 \% \\
\text { CE } 73 \% \\
\text { CP 27\% }\end{array}$ & $\begin{array}{l}\text { Curretage/enucleation } \\
88 \% \\
\text { Marginal/segmental } \\
\text { resection } 9.9 \%\end{array}$ & $21.6 \%$ & $\begin{array}{c}\text { Mean } \\
4.64 \\
\text { years }\end{array}$ \\
\hline
\end{tabular}

R: Right; L: Left; RL: Radiolucency; Mand: Mandible; Max: Maxilla; CE: Cortical Expansion; CP: Cortical Perforation; NR: Not Reported.

\section{CONCLUSION}

A high index of suspicion must be maintained for the timely diagnosis of GOC. Radiographic features are useful in determining the final diagnosis especially due to the non-specific clinical manifestations of this entity.

3D imaging is particularly valuable in visualizing the internal structure of the lesion and determining cortical integrity. We consequently suggest multiplanar imaging when GOC is suspected. Computed Tomography (CT) is especially important for very large or extra gnathic lesions.

\section{Acknowledgement}

Mrs. Marlise Coetzee - Administrator of Diagnostic Radiology museum at Faculty of Dentistry, University of the Western Cape.

\section{Conflict of interest}

No conflict of interest declared.

\section{References}

1. Gardner DG, Kessler HP, Morency R, Schaffner DL. The glandular odontogenic cyst: an apparent entity. J Oral Pathol Med. 1988; 17(8): 359-66.

2. Martin LHC, Speight PM. Odontogenic cysts: an update. Diagnostic Histopathol [Internet]. 2017; 23(6): 260-5. Available from: http://dx.doi.org/10.1016/j.mpdhp.2017.04.006.

3. Del Corso G, Pizzigallo A, Marchetti C, Tarsitano A. Central mucoepidermoid carcinoma in a young patient: A case report and review of the literature. J Oral Maxillofac Surgery., Med Pathol [Internet]. 2016; 28(1): 61 - 5. Available from: http:// dx.doi.org/10.1016/j.ajoms.2015.07.008.

4. Faisal M, Ahmad SA, Ansari U. Glandular odontogenic cyst Literature review and report of a paediatric case. J Oral Biol Craniofacial Res [Internet]. 2015; 5(3): 219-25. Available from: http://dx.doi.org/10.1016/j.jobcr.2015.06.011.

5. Padayachee A, Van Wyk CW. Two cystic lesions with features of both the botryoid odontogenic cyst and the central mucoepidermoid tumour: sialo-odontogenic cyst? J Oral Pathol Med. 1987; 16(10): 499-504.

6. Figueiredo NR, Dinkar AD, Khorate MM. Glandular odontogenic cyst of the maxilla: a case report and literature review. Pan Afr Med J [Internet]. 2016; 25: 1-7. Available from: http:// www.panafrican-med-journal.com/content/article/25/116/full/. 
7. Ogura I, Tsuchimochi M, Ono J, et al. Glandular odontogenic cyst: a report of four cases. Oral Sci Int [Internet]. 2017; 14(2): 43-9. Available from: http://dx.doi.org/10.1016/S13488643(17)30018-6

8. Fowler CB, Brannon RB, Kessler HP, Castle JT, Kahn MA. Glandular odontogenic cyst: analysis of 46 cases with special emphasis on microscopic criteria for diagnosis. Head Neck Pathol. 2011; 5(4): 364-75.

9. Kaplan I, Anavi Y, Manor R, Sulkes J, Calderon S. The use of molecular markers as an aid in the diagnosis of glandular odontogenic cyst. Oral Oncol. 2005; 41(9): 895-902.

10. Speight PM, Takata T. New tumour entities in the $4^{\text {th }}$ edition of the World Health Organization Classification of Head and Neck Tumours: odontogenic and maxillofacial bone tumours. Virchows Arch [Internet]. 2018 Mar 3 [cited 2018 Dec 8]; 472(3): 331-9. Available from: http://link.springer.com/10. 1007/s00428-017-2182-3.

11. David CM, Kastala RK, Jayapal N, Majid SA. Imaging modalities for midfacial fractures. Trauma (United Kingdom). 2017; 19(3): $175-85$
12. Kaplan I, Anavi Y, Hirshberg A. Glandular odontogenic cyst: A challenge in diagnosis and treatment. Oral Dis. 2008; 14(7): 575-81.

13. Chandra S, Reddy ESP, Sah K, Srivastava A. Maxillary glandular odontogenic cyst: An uncommon entity at an unusual site. Arch Iran Med. 2016; 19(3): 221-4.

14. Kurien NM, Kumar LKS, Uma PB, Vivek V, Joseph AP. An extensive swelling in the anterior mandible - A case report. Ann Med Surg [Internet]. 2017; 21: $30-3$. Available from: http://dx.doi.org/10.1016/j.amsu.2017.07.017

15. Chrcanovic BR, Gomez RS. Glandular odontogenic cyst: An updated analysis of 169 cases reported in the literature. Oral Dis. 2018; 24(5): 717-24.

16. Kaplan I, Gal G, Anavi Y, Manor R, Calderon S. Glandular odontogenic cyst: Treatment and recurrence. J Oral Maxillofac Surg. 2005; 63(4): 435-41.

\section{Do the CPD questionnaire on page 515}

The Continuous Professional Development (CPD) section provides for twenty general questions and five ethics questions. The section provides members with a valuable source of CPD points whilst also achieving the objective of CPD, to assure continuing education. The importance of continuing professional development should not be underestimated, it is a career-long obligation for practicing professionals.

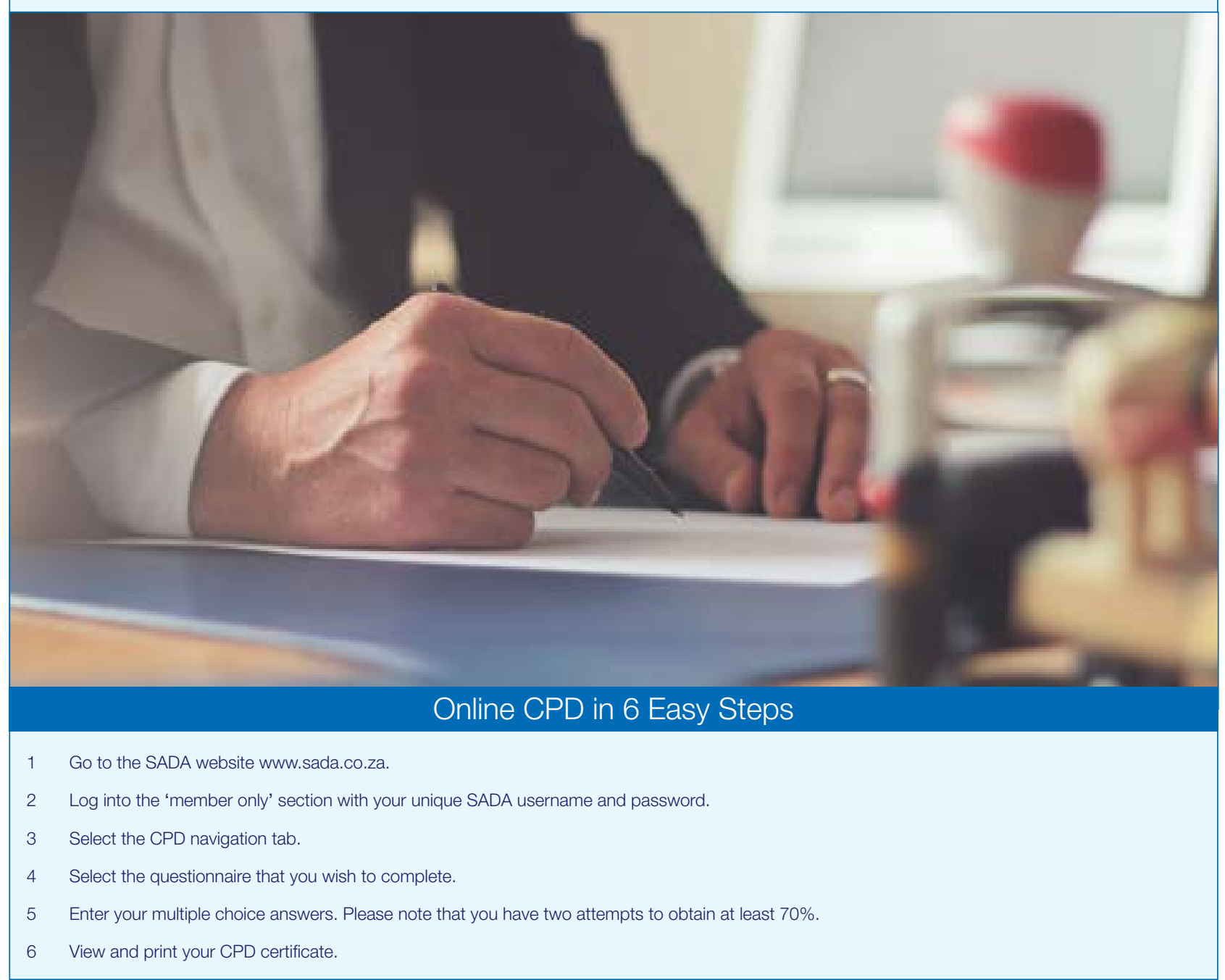

